\title{
Analysis of Children Values, Academic Socialization, and Motivation to Continue Junior High School Education
}

\author{
Nayla Humaeda* \\ Department of Family and Consumer Sciences, \\ Faculty of Human Ecology, \\ Bogor Agricultural University \\ Alfiasari \\ Department of Family and Consumer Sciences, \\ Faculty of Human Ecology, \\ Bogor Agricultural University \\ *Corresponding author: naylahumaeda.nh@gmail,com
}

\begin{abstract}
The aim of this research was to analyze the value of children, academic socialization, and motivation to continue junior high school education of the school-aged children in rural areas. This research used cross sectional design. The location of the research was determined purposively with the criteria of farming households with a big size of paddy land. The examples of this study were 100 children from complete families whose school-age children were selected by random proportional method. The participants of this research were 100 children from intact families who had children of elementary school selected and choosen by propotional random sampling. Result showed that the value of children was in moderate category for each dimension. There was a significantly positive correlation of dimension academic socialization in discussing between learning strategies and the value of psychological. Meanhile, parent's academic socialization was in the low category. This means that parents are still lacking in transforming the importance of education to children. The result showed a significant and positive correlation between parent's academic socialization and child's motivation to continue education. Parent's academic socialization also significantly influenced child's intrinsic motivation to continue education.
\end{abstract}

Keywords: motivation to continue education, parent's academic socialization, value of children

\begin{abstract}
Abstrak
Penelitian ini bertujuan menganalisis nilai anak, sosialisasi akademik, dan motivasi melanjutkan pendidikan sekolah menengah pertama pada anak usia sekolah di perdesaan. Lokasi penelitian terletak di Desa Ciasihan dan Desa Ciasmara, Kecamatan Pamijahan, Kabupaten Bogor. Contoh dalam penelitian ini berjumlah 100 anak yang berasal dari keluarga lengkap yang memiliki anak usia sekolah yang dipilih dengan metode acak proporsional. Hasil penelitian menunjukan nilai anak termasuk dalam kategori sedang untuk setiap dimensinya. Penelitian menemukan adanya hubungan positif signifikan antara sosialisasi akademik dimensi mendiskusikan strategi belajar dengan nilai psikologi. Sementara itu, sosialisasi akademik orang tua termasuk dalam kategori rendah. Hal ini berarti orang tua masih kurang dalam menyampaikan pentingnya pendidikan kepada anak. Hasil penelitian menunjukkan bahwa sosialisasi akademik orang tua berhubungan positif signifikan dengan motivasi anak melanjutkan pendidikan. Sosialisasi akademik orang tua juga berpengaruh terhadap motivasi intrinsik melanjutkan pendidikan.
\end{abstract}

Kata kunci: motivasi melanjutkan pendidikan, nilai anak, sosialisasi akademik orang tua 


\section{Introduction}

Education is one of the important factors to improve human resources. The importance of education for the Indonesia nation is reflected in the 1945 Constitution, which mandates that education is the right of every citizen. The aim of this is to educate the nation, but in fact the Indonesian who can get age-appropriate education is still not evenly distributed. Based on the data from CBS (2014), the higher education level, the lower the participation of school age population to go to school according to education level. This is the evident from the School Participation Rate (SPR), which declines as the education level gets higher.

Based on BPS data in 2013, SPR population aged 7-12 years reached 98.42 percent while the population aged 13-15 years APS only reached 90.81 percent. This means that less than ten percent of the population aged 7-12 years has not been able to continue their education to Junior High School. According to BAPPENAS (2003), economic issues are the causes of high dropout rates; moreover, these also cause them unable to continue their education. These children may not have parents who set high standards for their education, can not teach them to read, and do not have fund for schools. In addition, factors within the child can also be the cause of school dropouts, such as motivation to continue school.

Motivation can come from the children themselves (intrinsic) or from outside (extrinsic). Low motivation for school children can be caused by parents' attention and awareness for children's education (Sutiasnah 2015). Parents are too busy to work and they never ask children about the wishes of children go to school, so this make children demotivated to go to school.

Family is the first and most educational institutions for children. Parents have a very important role in guiding and assisting the child in the child's everyday life. Therefore, parents should provide parenting that is optimal for the growth and development of children. How to care is closely related to parents' perceptions of the value of children. Nauck and Klaus (2007) defines the value of children as parents' perceptions regarding the benefits or costs incurred when having children. Based on the research results Bahri and Hartoyo (2013), the value of psychology and social value of children in non poor families are not higher than those in poor families. This means that families that are not poor are more satisfied and happy to have children than that of poor families and more children receive a well in the hope the child can carry on the name and the family line. However, the economic value of children in poor families is higher than that in non-poor families. This means that poor families are more likely to agree that by having a child, parents feel the economic benefits, both in family income now and the backbone of the family. Poor families that have higher economic value as found Bahri and Hartoyo (2013), indicated that in rural families, one of which is characterized with higher poverty and a high economic value also to their child so that the child was supposed to provide economic benefits for families.

The parents' perception related to the value of children is assumed to affect the socialization provided by parents to children. According Trommsdorff (2001), parents perform a socialization to the child as well as transfer the value and behaviour expected within the children. Academic socialization is the ability of parents to communicate the expectations of academic achievement of children and encourage children to plan for the future (Lewis 2011). Through the process of socialization, the child will acquire the 
skills, knowledge and attitudes that are relevant to their function as a student The socialization process make a person know how one should behave in society and the environment.

The purpose of this study is to identify child characteristics, family characteristics, the value of children, academic socialization and motivation to continue education; analyze the relationship between variables; analyze the effect of child characteristics, family characteristics, and the value of the child towards the socialization of academic parents; and analyze the characteristics of the child, family characteristics, and academic socialization on the motivation to continue education

\section{Research Method}

This study used cross sectional design. The location of the research was determined purposively with the criteria of farming households with large paddy land area in Bogor - District Pamijahan. Data retrieval research was conducted in May 2015. The population in this study was families in rural areas with school age children $4^{\text {th }}$ and $5^{\text {th }}$ grades who live in rural areas in the district Pamijahan, Bogor. The sample in the study was 100 childrens. Sampling is done by proportional random sampling based on gender and the number of students in grade 4 and grade 5 in selected schools.

The data collected in this study are primary data obtained from interviews. Questionnaires of child value derived from instruments Sarwoprasodjo et al. (2013) with a Cronbach's alpha value of 0.850 and 34 valid statements. Questionnaires academic socialization of parents using the concept of Lewis (2011) had a Cronbach's alpha value of 0919 by 33 valid statements. Meanwhile, continuing education motivation questionnaire had a Cronbach's alpha value of 0875 by 20 valid statements which is a modification of Hasibuan (2010). Data were obtained and processed through a process of editing, coding, scoring, entry, cleaning, and data analysis. Data were analyzed using the software program Statistical Package for Social Science (SPSS) for Windows and Microsoft Excel. The analytical method used in this research is descriptive and inference analysis. Descriptive analysis is used to see the distribution of data and inferential analysis was used for correlation and multiple linear regression tests.

\section{Result}

\section{Children characteristic}

The results of this study, overall, the lowest age child is 9 years old and the highest age is 13 years old with an average age of 11 years. Based on the categories of gender, the number of boys and girls are 55 to 45 people. The average age of the boys was 11:24 and the average years of girls is 10.71 years. Almost all respondents (49\%) have a brother less than or equal to 2 and ranks middle child (48\%).

\section{Families Characteristic}

In this study, the youngest age of the father was at 27 years while maternal age was at 23 years. The oldest father's age was 80 years old and the oldest mother was 75 years old. The average age of father was 44.03 years old and mother's average age was 
38.19 years. Meanwhile, the latest education of parents was still very low. The average father's education was 6.12 years and 5.79 years of maternal education.

The type of work most widely owned by father was an entrepreneur with a percentage of $36 \%$. Meanwhile, another father profession was labor (26\%) and day laborers farmers (13\%). Then, almost three-quarters of women $(74 \%)$ did not work. Other professionals mothers by $11 \%$ as entrepreneur and others. Large families ranged between 3-10 people with an average of 5.3 people. Meanwhile, more than half of the families was included in the category of medium family (54\%).

\section{Value of Children}

Value of children based on Kagitcibasi (1982) in Nauck and Klaus (2007) is divided into three dimensions: the psychological value, economic value and social value. The results found that the psychological value (79.12) has the highest average value in comparison to the economic value (72.89) and social value (74.88). This means in the rural families, the child is considered psychologically more advantageous compared to the economic and social benefits.

Other results of the children value refers to dimension by categorization of the category that are of low, medium, and high. It is known that the entire largest proportion of the value dimension of children is in the middle category. Children are considered to give happiness, joy, and satisfaction for their parents (psychological value). In addition, children are considered to provide economic benefits for the elderly and are expected to assist parents in supplement family incomes (economic value). By having a child, parents also feel that children will ensure the continuity of the family and can improve the social status of the family (social value).

\section{Parents Academic Socialization}

Academic socialization is a child's perception of the way the parents in transmitting values related to the expectations, and behavior of parents towards the child's education consists of education and better jobs, put pressure on the educational value, communicate expectations for achievement, discuss learning strategies, plan and preparation for the future, and connect home and school assignments with the interests and goals of children. The study found that the obtained academic socialization of children is still relatively low. If it is viewed by the dimension too, almost all dimensions of academic socialization are included in the low category. This means that the child's perception of the academic socialization given by parents was still less than optimal. Children feel that their parents was enough to put pressure on the value of education, but they are still lacking in socializing the child in order to get an education and better jobs, less communicate the expectations of children's achievement, rarely discussing learning strategies with children, rarely invites children to make plans and preparations the future, and less to connect home and school assignments with the interests and goals of children.

\section{Motivation Continuing Education}

The motivation to continue education is the desire, both from within themselves (intrinsic) and from outside (extrinsic) to continue their education as possible. The results showed at children in rural areas, intrinsic motivation is higher than extrinsic motivation, meaning desire that comes from within the child to continue education is 
greater than the influence of external child. In addition, the motivation to continue education, both intrinsic motivation and extrinsic motivation is in middle category. This means that children in rural areas have enough desire to continue their education to Junior High School/equivalent, the desire comes from within the child as well as the influence of outside child.

\section{Relationships of Children Characteristics and Families Characteristic with Children Values, Parents Academic Socialization and Motivation to Continuing Education}

In Table 1 shows that the child's age is correlated significantly negative with the value of psychology and social value. That is, the older of the child's age, the lower the parents' expectations of the benefits of social psychology and child will be.

Table 1 The coefficient of correlation between children characteristics and families characteristics with the value of the child, academic socialization of parents, and the motivation to continue education

\begin{tabular}{lcccccc}
\hline \multicolumn{1}{c}{$\begin{array}{c}\text { Relationships } \\
\text { among variables }\end{array}$} & $\begin{array}{c}\text { Psychologi } \\
\text { cal Value }\end{array}$ & $\begin{array}{c}\text { Economic } \\
\text { Value }\end{array}$ & $\begin{array}{c}\text { Social } \\
\text { Value }\end{array}$ & $\begin{array}{c}\text { Academic } \\
\text { Socialization } \\
\text { Of Parents }\end{array}$ & $\begin{array}{c}\text { Intrinsic } \\
\text { motivation }\end{array}$ & $\begin{array}{c}\text { Extrinsic } \\
\text { motivation }\end{array}$ \\
\hline $\begin{array}{l}\text { Children characteristic } \\
\quad \text { Age }\end{array}$ & $-0.238^{*}$ & -0.010 & $-0.263^{* *}$ & -0.182 & -0.143 & -0.043 \\
$\quad \begin{array}{l}\text { Birth Order } \\
\text { Families characteristic }\end{array}$ & -0.015 & 0.081 & -0.008 & -0.027 & -0.090 & -0.134 \\
$\quad \begin{array}{l}\text { Father's age } \\
\text { Mother's age }\end{array}$ & -0.011 & 0.096 & 0.051 & -0.058 & -.0123 & -0.110 \\
$\begin{array}{l}\text { Length of } \\
\text { father's }\end{array}$ & -0.088 & 0.107 & -0.036 & -0.064 & -0.034 & -0.031 \\
$\quad \begin{array}{l}\text { education } \\
\text { Length of } \\
\text { mother's }\end{array}$ & $0.296^{*}$ & -0.049 & -0.061 & 0.023 & 0.070 & 0.122 \\
$\quad \begin{array}{l}\text { education } \\
\text { Income/capita }\end{array}$ & 0.133 & 0.016 & 0.174 & 0.115 & -0.066 & -0.072 \\
$\begin{array}{l}\text { Large of } \\
\text { families }\end{array}$ & 0.125 & -0.123 & -0.65 & 0.059 & -0.027 & -0.076 \\
\hline
\end{tabular}

Information: *= significance at $\mathrm{p}<0.05 ; * *=$ significance at $\mathrm{p}<0.01$

Older maternal education is associated significantily negative with psychological value and social value. This means that the longer the mother's education, the higher the expectations of parents to get benefits of psychological and social benefits perceived by having children. Meanwhile, the old father's education is related significantly negative to the value of psychology. This is in contrast to the findings of Hastuti (2011) which states that the father and mother education is positively associated with psychological value.

\section{Relationship between Children Value with Parent's Academic Socialization}

The results study in Table 2 found that psychological value is associated significantly positive with the socialization of discussing learning strategies. This means that the higher perception of parents to child benefit in giving pleasure, happiness, and a source of love and friendship, the better the child's perception of the socialization that 
provided by parents in discussing learning strategies will be, such as parents set the learning time of children at home or help a child in completing homework. Meanwhile, there is no significant correlation between the economic value and social value to the academic socialization of parents.

Table 2 The correlation coefficient between the child value with parents academic socialization

\begin{tabular}{lccccccc}
\hline \multirow{2}{*}{$\begin{array}{l}\text { Relationships among } \\
\text { Variable }\end{array}$} & \multicolumn{7}{c}{ Academic Soocialization } \\
\cline { 2 - 8 } & 1 & 2 & 3 & 4 & 5 & 6 & Total \\
\hline Psychological value & 0.081 & 0.124 & 0.131 & $0.234 *$ & 0.098 & 0.166 & 0.181 \\
Economical value & 0.165 & 0.028 & 0.054 & 0.178 & 0.120 & 0.027 & 0.118 \\
Social value & 0.094 & 0.108 & 0.043 & 0.150 & 0.120 & -0.000 & 0.111
\end{tabular}

Note: 1 = get better education and jobs; 2 = put pressure on the value of education; $3=$ communicate expectations for achievement; $4=$ discuss learning strategies; $5=$ make plans and preparations for the future; $6=$ Connecting home and school assignments with the interests of children; $*$ Significance at $\mathrm{P}<0.05$

\section{Relationship between Parents Academic Socialization with Motivation to Continuing Education}

Table 3 shows that there is a significantly positive relationship between academic socialization of parents with the motivation to continue education, both intrinsic motivation and extrinsic motivation. If seen from the dimensions of academic socialization of parents, almost all dimensions of academic socialization of parents are associated significantly positive with the motivation to continue their education.

Table 3 The correlation coefficient between the academic socialization of parents with the motivation to continue education

\begin{tabular}{lcc}
\hline Relationships between variables & \multicolumn{2}{c}{ Motivation to continue study } \\
\cline { 2 - 3 } & Intrinsic motivation & Extrinsic motivation \\
\hline Academic Socialization & $0.354^{* *}$ & $0.293^{* *}$ \\
Get better education and job & 0.154 & 0.170 \\
Put pressure on the value of education & $0.308^{* *}$ & $0.281^{* *}$ \\
Communicate expectation for achievement & $0.322^{* *}$ & $0.272^{* *}$ \\
Discuss learning strategies & $0.324^{* *}$ & $0.235^{*}$ \\
Make a plan and preparation for the future & 0.177 & 0.158 \\
Connect the home and school assignments & $0.315^{* *}$ & $0.209^{*}$ \\
with the interests and goals of children & & \\
\hline Note $*=$ significance at $\mathrm{p}<0.05 ; * *$ Significance of $\mathrm{p}<0: 01$ &
\end{tabular}

Note: $*=$ significance at $\mathrm{p}<0.05 ; * *=$ Significance of $\mathrm{p}<0: 01$

Higher child's perception related to the socialization of parents in stressing the importance of education to the child, either by parents talked about the importance of education, asked what activities their children do in school, or advised children that science that children receive at school will be useful for the future to further improve children's motivation to continue their education to a higher level again. 


\section{Effect of Characteristics of the Child, Characteristics of Family and Children Values to Socialization Academic of Parents}

After analyzing the effects of child characteristics, family characteristics, and the children value towards the parents socialization of academic, it was found that the models were found to have no significant effect, using either the enter (sig 0.420) or backward method (sig 0.420) in the multiple linear regression analysis with software SPSS. This means the child's characteristics (age and birth order of children), family characteristics (maternal age, duration of maternal education, family income per capita, and a large family), and the value of children (grades psychology, economic value and social value) do not affect the parents academic socialization.

\section{Effect of Characteristics of the Child, Characteristics of Family and Socialization} Academic of Parents on Motivation to Continue Education

Based on the effect results on intrinsic motivation to continue education in Table 4, the value of Adjusted R Square of 10.2 percent, which means that the variable in the table affects 10.2 percent of the intrinsic motivation of children to continue their education. In addition, note also that the academic socialization $(\beta=0.326)$ significant positive effect on children's intrinsic motivation to continue education, which means that each increase of one academic socialization score will raise the scores of intrinsic motivation to continue education by 0326 points.

Table 4 The results of multiple regression analysis of child characteristics, family characteristics, and academic socialization of parents on intrinsic motivation to continue education

\begin{tabular}{|c|c|c|c|c|}
\hline \multirow[t]{2}{*}{ Independent variabel } & \multicolumn{2}{|c|}{$\begin{array}{l}\text { Unstandardized } \\
\text { Coefficient }\end{array}$} & \multirow{2}{*}{$\begin{array}{c}\text { Standardized } \\
\text { Coefficient }\end{array}$} & \multirow[t]{2}{*}{ Sig. } \\
\hline & $\mathrm{B}$ & Std. Eror & & \\
\hline (Constant) & 85.356 & 24.258 & & 0.001 \\
\hline Chil's age (year) & -2.091 & 1.883 & -0.110 & 0.270 \\
\hline Birth order & -1.272 & 1.278 & -0.143 & 0.322 \\
\hline Mother's age (year) & .143 & .251 & 0.076 & 0.570 \\
\hline Length of mother's education (year) & -.852 & .742 & -0.119 & 0.254 \\
\hline Family income (Rp/capita/month) & $-3.253 \mathrm{E}-6$ & .000 & -0.094 & 0.340 \\
\hline Family Larges & -.257 & 1.209 & -0.023 & 0.832 \\
\hline Parent's Academic Socialization & 0.326 & 0.087 & 0.369 & $0.000 * *$ \\
\hline $\mathrm{F}$ & \multicolumn{4}{|c|}{2.606} \\
\hline Sig. & \multicolumn{4}{|c|}{0.017} \\
\hline $\mathrm{R}^{2}$ & \multicolumn{4}{|c|}{0.165} \\
\hline Adjusted R Square & \multicolumn{4}{|c|}{0.102} \\
\hline
\end{tabular}

Description: $* *=$ Significant at $\mathrm{p}<0.01$

The study also tested the hypothesis of variables influence in child characteristics, family characteristics, and academic socialization of parents to extrinsic motivation in continuing education. Use of the "enter" method on multiple linear regression analysis with SPSS software on that model found no significant effect. Therefore, this study attempts to test the effect by using a backward analysis method at the 0.05 significance level. 
The test results found that the significant model is to exclude the child's age variable as an independent variable (free). The test results on the effect of extrinsic motivation in Table 5 Adjusted R Square value attained by 7.3 percent, meaning that the variable in the table by 7.3 percent against the influence of extrinsic motivation to continue education. Academic socialization $(\beta=0.250)$ give significantly positive effect on extrinsic motivation to continue education, meaning that each increase of one academic socialization score will raise the scores of extrinsic motivation to continue education at 0.250 points.

Table 5 Results of multiple regression analysis of child characteristics, family characteristics, and academic socialization of parents of extrinsic motivation to continue education

\begin{tabular}{|c|c|c|c|c|}
\hline \multirow[t]{2}{*}{ Independent variabel } & \multicolumn{2}{|c|}{$\begin{array}{l}\text { Unstandardized } \\
\text { Coefficient }\end{array}$} & \multirow{2}{*}{$\begin{array}{c}\text { Standardized } \\
\text { Coefficient }\end{array}$} & \multirow[t]{2}{*}{ Sig. } \\
\hline & B & Std. Eror & & \\
\hline (Constant) & 62.857 & 10.191 & & 0.000 \\
\hline Chil's age (year) & -1.589 & 1.128 & -0.206 & 0.162 \\
\hline Birth order & 0.206 & 0.221 & 0.125 & 0.354 \\
\hline Mother's age (year) & -0.568 & 0.650 & -0.091 & 0.385 \\
\hline Length of mother's education (year) & $-2.398 \mathrm{E}-6$ & 0.000 & -0.080 & 0.423 \\
\hline Family income (Rp/capita/month) & -0.555 & 1.068 & -0.057 & 0.604 \\
\hline Family Larges & 0.250 & 0.077 & 0.325 & $0.002 *$ \\
\hline $\mathrm{F}$ & \multicolumn{4}{|c|}{2.302} \\
\hline Sig. & \multicolumn{4}{|c|}{0.041} \\
\hline $\mathrm{R}^{2}$ & \multicolumn{4}{|c|}{0.129} \\
\hline Adjusted R Square & \multicolumn{4}{|c|}{0.073} \\
\hline
\end{tabular}

Description: $* *=$ Significant at $\mathrm{p}<0.01$

\section{Discussion}

Motivation comes from the Latin movere which means moving. According Ormrod (2009), motivation keeps students engaged, places students in a particular direction, and ensures that students keep moving in achieving learning goals. Motivation is divided into two category, that is, intrinsic motivation and extrinsic motivation. In this study, the definition of intrinsic motivation is a desire that comes from the students to continue their education to Junior High School/equivalent and extrinsic motivation is a desire that comes from outside the student to continue his education. The results of this study showed that motivation to continue education at school-age children in rural areas included in the medium category, which means that school-age children in rural areas is quite eager to be able to continue their education to Junior High School/equivalent. It was also found that intrinsic motivation is greater than extrinsic motivation. These results are consistent with findings Lemos \& Verissimo (2014) who found that school-age children who are at high-class have intrinsic motivation that is higher than extrinsic motivation. It happened because of the weakening of the impact from an external source,

The study found that motivation to continue their education, both intrinsic motivation and extrinsic motivation are influenced by academic socialization of parents. One of the causes of less high motivation to continue education is the lack of academic 
socialization that parents give to the children. Academic socialization is the family's ability to transmit educational values to children. The study found that academic socialization of parents included in the low category, which means the child's perception of the socialization provided parent education related child still low. Parents are not optimally communicate the importance of education for children and parents are also not actively involved in the learning process of children, such as helping with homework or ask what activities their children do in school or set hours of study at home.

The involvement of parents affect the academic outcomes of school children (Orozco 2008). The study found that the academic socialization gives related and significant effect on the motivation of continuing education. That is, good ability of parents in emphasizing the importance of educational value, communicate expectations of parents for children to achievement, taking children to discuss learning strategies, linking chores and school interests and objectives, socializing in order to children get the better education and job, and making plans and preparations for the future of children can increase the child's motivation to continue their education. This is in line with research Tan, Ismanto \& Babakal (2013) who found that there is a relationship between parental support and child motivation to learn. Support from parents, both good physical and psychological support is much needed by children in promoting the spirit of learning. Shortages or lack of motivation, both internal and external will lead to less enthusiasm with the students in the process of teaching learning materials both at school and at home (Shah, 2012 in Tan, Ismanto \& Babakal 2013). The lack of the spirit of the child in the learning process can result in lower motivation to continue their education.

Hastuti (2011) found that the higher value of a child affects the parenting applied in a family. This study found that children values in rural families included in the category. This means that parents in rural enough to feel the benefits to their children in the family. The results found no effect on the academic socialization of children against parents so that the study can not explain more about the relationship between the value of the child with the motivation to continue their education. However, based on the test results of the relationship between the value of academic socialization of children with their parents, there is a significantly positive correlation between the value of psychology and socialization in discussing learning strategies. This means, the higher expectations of parents related to child benefit in giving happiness and joy in the family, the better the parents provide socialization in discussing learning strategies in children.

Based on the relationship test results, it was found that the child's age is correlated significantly negative to the value of psychology and social values, which means the older age of the child, it will make parental expectations regarding the benefits of psychological and social benefits of children has declined. This might be due to the Theory of Economic Families (Bryant and Zink 2006 in Maidah 2014) which states that the increasing age of the child, the investment over time decreases while the investments of money will increase. It has been suggested that older child make parents expect children to provide more economic benefits than the psychological and social benefits. Meanwhile, the length of mother's education is associated significantly posistive with psychological value and social value. This is in line with research Hastuti (2011) who found that the mother's education relates to the value of the child. This means that the higher of mother's education, the higher the expectations of parents of children in giving satisfaction to the family. Parents with higher education is expected 
to have the knowledge and higher awareness about the importance of the child so that the perception of the value related to the higher child. In addition, there is no relationship between the characteristics of the child and family characteristics with parental academic socialization and motivation to continue education.

\section{Conclusion}

\section{Conclusion and suggestion}

The results showed that at the characteristics of children, the average age was 11 years and was more dominated by boys. In addition, most of the children are in the middle of the birth order. For family characteristics, the average age of fathers are 44.03 years and the length of father's educations is 6.12 years or completed primary school, while the average age of mothers are 38.19 years and length of mother's education is 5.79 years or did not finish school.

The study found that the obtained academic socialization of children is still relatively low. If it is viewed by the dimension too, almost all dimensions of academic socialization are included in the low category. The results showed at children in rural areas, intrinsic motivation is higher than extrinsic motivation, meaning desire that comes from within the child to continue education is greater than the influence of external child. The study found that the children value belong to the medium category in every dimension. The results found that the child's age has a negative association, and length of education of a mother is correlated positively with psychological value and social value. Meanwhile old father's education is negatively related to the value of psychology. Based on the test results among the variables studied, there is a positive relationship between the value of psychology with academic socialization dimensions in discussing learning strategies. Regression test results found no effect on the value of the child's academic socialization of parents so that this research has not been able to explain further the relationship between the value of the child with the motivation to continue their education.

Socialization academic parents in rural areas classified in the low category, meaning that the child's perception on how parents socialize the importance of educational value in children are low. The study also found that there is a positive relationship between academic socialization and motivation to continue education. In addition, the motivation to continue education for children in rural areas included in the medium category. Intrinsic motivation is greater than extrinsic motivation. From the results of the regression test, the factors that most influence the intrinsic motivation to continue education is the academic socialization.

\section{Suggestion}

The results showed that socialization academic positively affects motivation to continue school. Therefore, it is suggested that the family must pay more attention to the education of children. Parents should be aware that children are very valuable and important to pay attention to the education and future of children. Parents are expected to provide facilities and infrastructure to support the children's learning process and begin to invite children to talk about the importance of education and begin to plan for the future of children. In addition, children also need to better understand the importance of education for the future and have a desire from within to continue 
education as long as possible. Further research is expected to examine more deeply the factors that affect children's motivation to continue their education at school-age children in rural areas.

\section{Reference}

[CBS] Central Bureau of Statistics. [The unknown]. School enrollment rates (APS) by province, 2003-2013. [Internet]. [Downloaded 2014 Des 31]. Available at: http://www.bps.go.id/linkTabelStatis/view/id/1527.

. [The unknown]. School enrollment rates (APS) by province, 2003-2013.

[Internet]. [Downloaded in 2014 Des 31]. Available at: http://www.bps.go.id/linkTabelStatis/view/id/1527.

Bahri NM, Hartoyo. 2013. Investment behavior of children in poor and non-poor families. JIKK. 6 (3): 190-198.

BAPPENAS. 2003. Peningkatan Akses Pendidikan Lebih Berkualitas. Accesed from ://www.bappenas.go.id/files/2513/5098/8841/bab-27---peningkatan-aksespendidikan-lebih-berkualitas_20090202213335_1758_27.pdf (Diunduh pada 2014 Des 31)

Hasibuan RD. 2010. DII Nursing student motivation to continue their education to graduate level in the Faculty of Nursing USU [thesis]. Medan (ID): University of North Sematera.

Hastuti R. Analysis of the value of children, the quality of care, and the development of school-age children in the family rubber farmers and smallholders in Bungo [thesis]. Bogor (ID): Institut Pertanian Bogor.

Lemos MS, Verissimo L. 2014. The relationships between intrinsic motivation, extrinsic motivation, and achievement, along elementary school. Social and Behavioral Sciences. 112 (2014): 930-938.doi: 10.1016 / j.sbspro.2014.01.1251.

Lewis M. 2011. Academic socialization's role in middle school and high school parent involvement. [Internet]. [Downloaded in 2015 Mar 15]. Available at: http://www.centerschool.org/papirc/documents/academicsocializa tion.pdf

Maidah R. 2014. Relationship allocation of parenting time and parenting mothers with school-age child welfare on farm families [thesis]. Bogor (ID): Institut Pertanian Bogor.

Nauck B, Klaus D. 2007. The varying Value of Children: Empirical Results from Eleven Societies in Asia, Africa and Europe. SAGE.555 (4): 487-503.doi: 10.1177 / 0011392107077634.

Ormrod JE. 2009. Educational Psychology: Helping Students Grow. Kumara A, translator; Rahmat R, editors. Jakarta (ID): publisher. Translation of Educational Psychology Developing Learners. 2nd Ed.

Orozco GL. 2008. Understanding the culture of the low-income immigrant Latino parents: Key to involvement. The School Community Journal. 18 (1): 21 - 37.

Sarwoprasodjo S, Puspitawati H, Alfiasari, Muljono P, Mintarti. 2013. Development of a model family members protection through 2013. Posdaya LPPM-IPB. Bogor (ID): Institut Pertanian Bogor.

Sutiasnah RA. 2015. Factors leading to dropouts (Studies (MI) and MTs (MTs) Nurul Wathan Vortex 8 Enok District of Indragiri Hilir). Jom Fisip.2 (1). 
Tan JH, Ismanto AY, Babakal A. 2013. The relationship between parental support and motivation to learn at school-age class IV and V in SD Negeri Kawangkoan Kalawat. e-Kp: vol 1 (1). [Internet]. [Downloaded in 2015 Mar 13]. Available at: http://ejournal.unsrat.ac.id/index.php/ JKP / article / viewFile / 2191/1749

Trommsdorff G. 2001. Value of children and intergenerational relations: a cross-cultural psychological study. Pp, 6-14. 